\title{
Comparison of the Effect of Implementation of Blended Learning and Peer Education Methods With the Improvement of Student Learning Outcomes in Block 4.C Course (Midwifery Care in Labor and High Risk Postpartum)
}

\begin{abstract}
Aldina Ayunda Insani ${ }^{*}{ }^{*}$ Uliy Iffah $^{2}$
${ }^{1}$ Bachelor of Midwifery at Medical Faculty, University of Andalas, Indonesia

Bachelor of Midwifery at Medical Faculty, University of Andalas, Indonesia

*Corresponding author.Email: aldinaayundainsani@med.unand.ac.id

ABSTRACT

Midwifery education uses a new paradigm, namely the Problem Based Learning (PBL) method. In connection with the era of the industrial revolution 4.0, technological advances and the situation of the Covid-19 pandemic, a renewal of the learning method was carried out, namely the Blended Learning system in the i-Learn application combined with peer education. The purpose of this study was to improve student learning outcomes in the Block $4 \mathrm{C}$ course by comparing the effects of the implementation of blended learning and peer education methods with previous ones using face-to-face systems.

The research subjects were the intervention group (class 2019 students using the I-Learn application, video and peer education) and the control group (students class 2018 with a face-to-face system). The activity was carried out for 5 weeks and the 6th week an assessment was carried out for all aspects of the learning method. Based on the research results, it was found that student learning outcomes had increased and was above the average (47.82\%), and there were no students who repeated the $4 \mathrm{C}$ block. Limited efficiency of package quota required for all students.
\end{abstract}

Keywords: learning methods, blended learning, peer education, student assessment

\section{INTRODUCTION}

Midwifery education uses a new paradigm, namely the PBL (Problem Based Learning) method, where at the basic level students must master learning techniques and it is hoped that later they will be able to learn continuously throughout their lives. Students are also required to master information technology that can be applied later in lectures including communication in the field, from interpersonal communication to communicating with various parties (doctors, other health workers and other non-health workers) either verbally or nonverbally. Mastery of this basic level of education is absolute, because it is a prerequisite for a student to be able to continue learning at the next stage. After participating in this module, it is hoped that they will have a solid mindset (cognitive restructuring) to be able to achieve core competencies which include a number of knowledge, skills and attitudes, namely lifelong learning skills, skills in communicating as a prospective midwife, understanding moral, ethical and legal aspects. in carrying out the profession. ${ }^{1}$

In connection with the Covid-19 pandemic situation and taking into account the expanding and increasing number ofCovid-19 patients who tested positive nationally and the increasing number of Patients Under Supervision (PDP) in the West Sumatra Region, the leadership of Universitas Andalas and the Faculty of Medicine, Universitas Andalas decided to take policies in accordance with the Circular of the Chancellor of Universitas Andalas Number: 8 / UN.16.R / SE / 2020 concerning Campus Activities in the Context of Covid19 Pandemic Alert and Circular of the Dean of the Faculty of Medicine, Universitas Andalas Number 2055 
/ UN16.2 / SE / 2020 Regarding the Prevention and Control of Covid-19 in the Faculty of Medicine, Universitas Andalas, then students of the Undergraduate Midwifery Study Program do not attend direct / face-toface lectures for the specified time, so the learning process in Block 4.C is carried out online or Distance Education by utilizing technology and continuing to do peer education or peer learning adjusted to the situation and conditions there so that they still pay attention to the achievement of the competencies that students must obtain. ${ }^{1}$

\section{Brief Description of Block}

Block 4.C which entitled Midwifery Care for HighRisk Childbirth and Childbirth, is a block that must be studied by semester IV students in the Undergraduate Study Program of Midwifery, Faculty of Medicine, Universitas Andalas. Students who take part in the learning in this course block give students the opportunity to understand concepts, changes in labor and childbirth with high risks. By understanding this concept, students are expected to be able to carry out midwifery care management during childbirth and childbirth with high risk according to the needs of the mother and in accordance with the authority of the midwife. Thus mastery of the material in Block $4 \mathrm{C}$ is important, because it will provide provisions for students in providing high quality high-quality midwifery care for childbirth and postpartum.

Lessons are prepared in the form of lectures by experts in the appropriate field, tutorial discussions, and skills training in the laboratory. This block runs for 5 weeks, each week will be discussed 1 module, so this block will discuss 5 modules. In addition to expert lectures, students will carry out clinical skills training. Each week there will be a plenary discussion with topics tailored to lectures and tutorial materials. At the end of the block, there will be an evaluation of the $4 \mathrm{C}$ block theory learning in the form of CBT. ${ }^{1}$

\section{Objectives or Outcomes}

After all of these lecture and skill activity programs are completed, students are expected to have abilities including attitudes, general skills, special skills (Care providers, Communicators, Community Leaders, Decision Makers and Managers), and knowledge. ${ }^{1}$

\section{RESEARCH METHOD}

This study uses a comparative study. Bivariate analysis was categorical correlative using t-test, to test the hypothesis using Mc.Nemar. ${ }^{2}$

\section{Learning Method Development}

Problem-based learning (PBL) is a learning strategy for students to learn together in a small group through two main learning activities, namely small group discussions facilitated by a tutor and independent learning. ${ }^{3}$

PBL is a form of Student Center Learning (SCL) method that is more focused and structured. Unlike the pure SCL, students are given flexibility in determining the scope of the material being studied according to their interests. In PBL learning, the scope of learning is more focused and specific.

The scope of learning in PBL is based on specific learning objectives that are detailed in the curriculum. The amount of time spent in the PBL process is also more limited than the amount of time spent on pure SCL. In pure SCL, students are given the flexibility to determine the amount of time they need to complete their inquiry, while in PBL students must complete the achievement of their learning goals within the time frame determined by the educational institution. In pure SCL, students can work individually based on their respective interests, so that they do not depend on the learning outcomes of other students. Whereas in PBL, the achievement of learning objectives by a student can be influenced by the results of extracting information from their peers in small groups because the information obtained by each student will be discussed to perfect the knowledge they gain. ${ }^{3}$

Problem solving is not the sole objective of the PBL process. Problems or scenarios are used as a stimulus for the learning process to increase knowledge and understanding of the learning objectives set in the curriculum. So that PBL can also be used to facilitate students to gain basic knowledge. Thus, PBL not only facilitates the acquisition of problem solving skills, but also the acquisition of knowledge and understanding, and several other soft skills such as communication, teamwork, independence and responsibility for learning, sharing information and respecting others. ${ }^{3}$

\section{Scheming}

a. The lecturer identifies, determines, and classifies learning objectives that will be discussed in each PBL learning session.

b. The lecturer arranges, chooses or looks for the right scenario to stimulate students to learn the learning objectives that have been set for each PBL session. Scenarios can be in the form of cases, film clips, pictures, news clips and others.

c. The lecturer estimates the schedule for the implementation of the 1st PBL tutorial, the amount of independent study time needed to achieve all the learning objectives set for the PBL session and the schedule for the 
implementation of the 2nd PBL tutorial.

d. The lecturer prepares a student activity assessment rubric during the tutorial process which consists of attendance, creativity, relevance, attitude and other assessment points deemed necessary.

e. The lecturer divides students into small groups which can consist of 5-10 students per group, each group should ideally be facilitated by a tutor.

f. PBL tutors do not have to be lecturers in the related fields discussed in the scenario. PBL tutors can be anyone who can carry out the role, with the following roles:

1) Helping the PBL group leader maintain group dynamics.

2) Ensuring groups are able to complete the learning objectives that have been set.

3) Ensure that all students have done their job correctly.

4) Help suggest a format for presenting appropriate independent learning outcomes for group members.

5) Encourage students to evaluate their understanding of the material by asking questions, explaining the material in their own words with pictures and schemes.

6) Provide feedback to students regarding their participation in the tutorial process and regarding the achievement of learning objectives.

The learning method is carried out during tutorials, as well as introductory lectures, plenary discussions and topic discussions. Each activity carried out will be presented and all materials uploaded to i-learn by each person in charge of the group. In the I-learn application, a slot is provided which is a vehicle for uploading materials and discussions among students (peer education).

\section{Student Assessment Development}

Development of a student assessment system that includes: process assessment, results assessment, selection of assessment techniques according to competency levels. $^{2}$

\section{Learning outcomes}

Learning outcomes for affective, cognitive or psychomotor elements. The distribution of the final value expected is $>80$ (quality value $=\mathrm{A})$.

\section{Student response to the development of applied learning methods and assessment systems}

Student responses are carried out by filling in a questionnaire as an evaluation of the learning methods used in box 4.C and are expected to improve student competency mastery.

\section{RESULTS AND DISCUSSION}

\subsection{Sample Characteristics}

The sample in this study was 46 students of Class 2018 who were grouped into 5 groups and the PBL lecture system by applying blended learning for each lecture activity. The comparison group was 44 students of class 2017 with a face- to-face PBL lecture system for each lecture activity.

\subsection{Lecture Results Blended Learning and Peer Group Education methods}

\section{Guide Block}

The Block Coordinator together with the members have prepared a Block guidebook for tutors, introductory lecturers, and students in the form of soft files and sent via email and whatsapp media. The 4.C Block Guide can also be accessed by students on the ilearn page with the web address http://fk.ilearn.unand.ac.id/course/view.php?id=84 0 along with lecture topics and lecture schedules during the block take place.

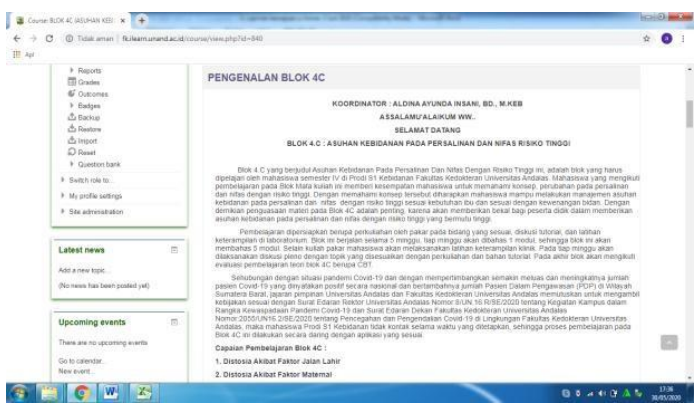

Figure 1. I-learn Pages for Block 4.C

\section{Lecture System}

4.C block lasts 5 weeks with activities :

\section{a. Tutorial}

Students consist of 5 groups of 5 tutors who have received Tutor training. Each tutor has been given a tutorial assessment sheet which includes an assessment of aspects of discipline, activeness and creativity, the relevance of the opinions conveyed to existing literature 
and attitudes. Tutorial activities are carried out using the Zoom Meeting application with existing links from study programs and student application links. For example, the Zoom Meeting link used is https://us04web.zoom.us/j/5635038943. Every Monday $09.30-11.30$ a tutorial is done by applying the seven jumps method for steps 1-4. Every Wednesday 09.30 11.30 a tutorial is done by applying the seven jumps method for steps 5-7.

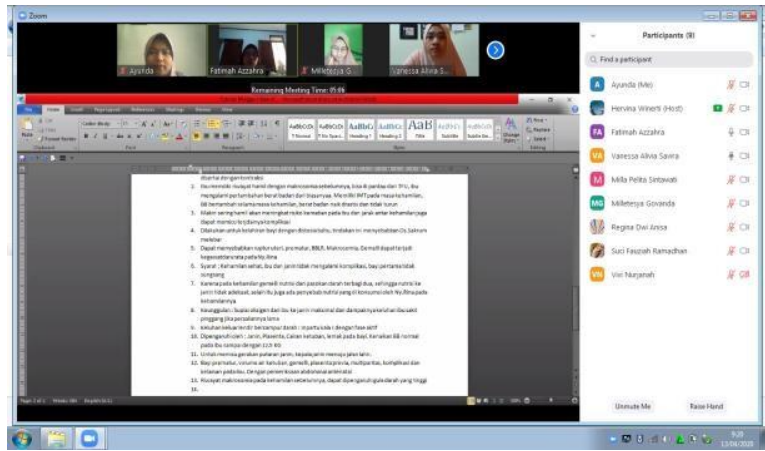

Figure 2. Tutorial Block 4.C Group 1 Week 1 Day 1 Activities with the Zoom Meeting application

\section{b. Introductory Lecture}

Each week there are 6 introductory lecture topics given by lecturers from related sections. Introductory lectures aim to provide an overview of students related to learning outcomes for the week. Introductory lecture activities are carried out using the Zoom Meeting application with the existing link from the study program, namely kebidananzoom.fkunand@gmail.com.

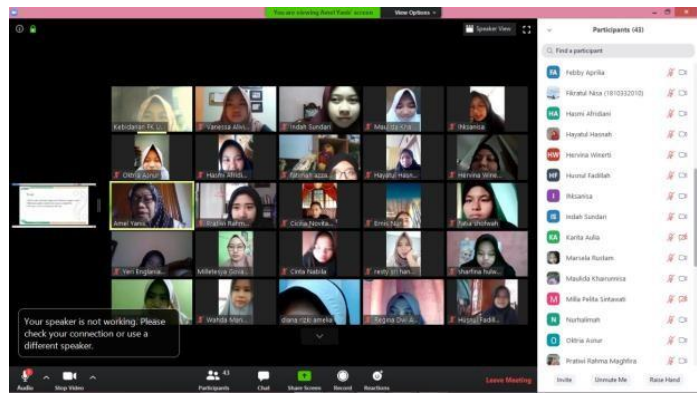

Figure 3. Introductory Lecture Using Applications Zoom Meeting

\section{c. Discussion Topics}

Students consist of 5 groups with 5 responsible lecturers. Each responsible lecturer provides a description of the topic according to the theme that has been determined for the week. Each person in charge provides an assessment that includes cognitive, affective students. Discussion topics are not only literature review but also include case studies provided by the lecturer concerned. The activity was carried out 2 times with the first meeting of students doing independent learning in groups and the second meeting with the lecturer concerned by explaining the results of group learning.
Every activity has a report which will be uploaded by students at i-learn.

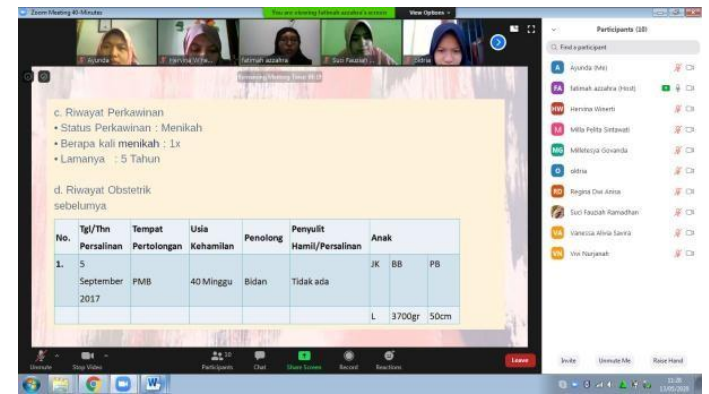

Figure 4. Topic Discussion Using the Zoom Application

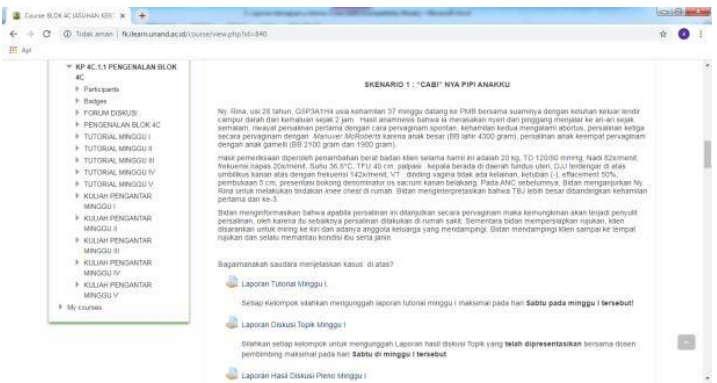

Figure 5. Must Topic Discussion Report uploaded On Ilearn

\section{d. Plenary Discussion}

Plenary discussions are held on Fridays each week and moderated by the lecturers who have been appointed at the beginning of the block. The plenary discussion was also attended by speakers who were lecturers who gave introductory lectures that week. Each group has the same opportunity to appear and present the results of the tutorial activities that week. There is a question and answer session and sharing learning objectives between groups so that each student has the same competence and understanding.

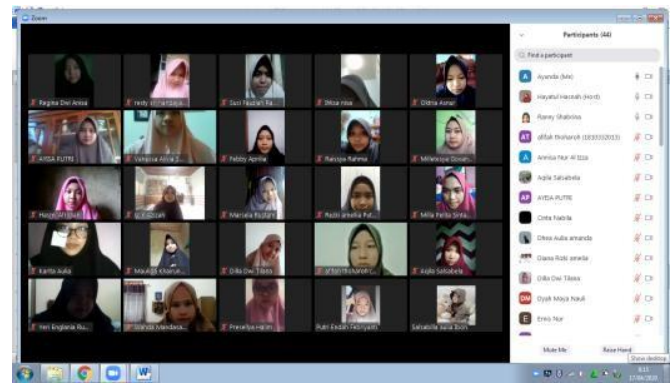

Figure 6. Plenary Discussion Using the Zoom Application

Learning with the Peer Group Education method Each group of students does group learning related to LO obtained during the tutorial. There is a chairperson for each group and a secretary who will guide the group discussion and be conducted online. Each activity report will be uploaded on i-learn. 


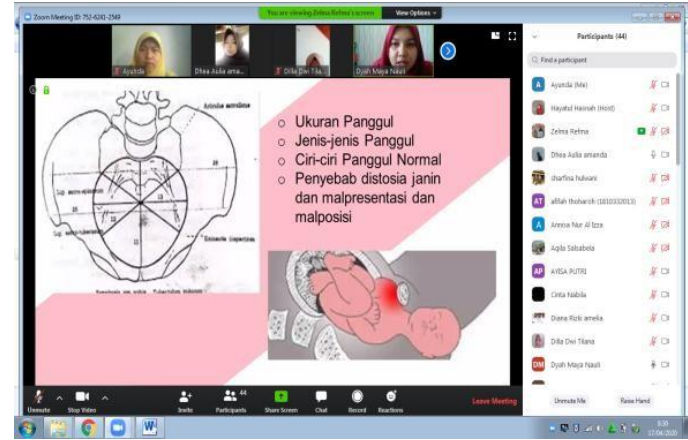

Figure 7. Peer Group Education discussions using Zoom Meeting Application

\subsection{Comparison and Effects of Blended Learning, Video and Peer Education on Block $4 C$ for the 2019-2020 Academic Year}

Block 4.C (Midwifery Care for High-Risk Labor and Childbirth) has a goal that students must be able to explain the LO that has been achieved each week and explain the midwifery care provided in high-risk labor and postpartum cases. To find out the level of student ability, an assessment is carried out for each existing lecture activity. Among the tutorials, an assessment is carried out at each totorial meeting every week. The assessment of the topic discussion was carried out on the 2nd day of the discussion each week and the final assessment was carried out by the computerized system examination at the 6th week. The following is the frequency distribution of the 44 samples in block 4.C.

Table 1. Comparison of Block Value 4.C for academic year 2018-2019 and academic year 2019-2020

\begin{tabular}{|c|c|c|c|c|}
\hline Value & \multicolumn{2}{|c|}{ AY 2018-2019 } & \multicolumn{2}{|c|}{ AY $2019-2020$} \\
\hline Range & $\bar{F}$ & $\%$ & $\mathrm{f}$ & $\%$ \\
\hline $75-79$ & 5 & 11,36 & 8 & 17,39 \\
\hline $70-74$ & 20 & 45,45 & 14 & 30,43 \\
\hline $65-69$ & 17 & 38,64 & 15 & 32,61 \\
\hline $60-64$ & 1 & 2,27 & 6 & 13,04 \\
\hline $55-59$ & 0 & 0 & 3 & 6,52 \\
\hline $45-49$ & 1 & 2,27 & 0 & 0 \\
\hline Total & 44 & 100 & 46 & 100 \\
\hline
\end{tabular}

Table 2. The Effect of Blended Learning, Video and Peer Group Education on Blok 4C academic year 20192020

\begin{tabular}{c|l|l|c|c|c}
\hline \multirow{2}{*}{$\begin{array}{c}\text { Value } \\
\text { Range }\end{array}$} & \multicolumn{2}{|c|}{$\begin{array}{l}\text { AY 2018- } \\
2019\end{array}$} & \multicolumn{2}{c|}{ AY 2019- } & \multirow{2}{*}{$\begin{array}{c}\rho \\
\text { value }\end{array}$} \\
\cline { 2 - 5 } & F & $\%$ & f & $\%$ & \\
\hline $75-79$ & 5 & 11,36 & 8 & 17,39 & \\
\hline $70-74$ & 20 & 45,45 & 14 & 30,43 & \multirow{2}{*}{0,001} \\
\hline $65-69$ & 17 & 38,64 & 15 & 32,61 & \\
\hline $60-64$ & 1 & 2,27 & 6 & 13,04 & \\
\hline $55-59$ & 0 & 0 & 3 & 6,52 & \\
\hline
\end{tabular}

\begin{tabular}{l|l|l|c|l|l}
\hline $45-49$ & 1 & 2,27 & 0 & 0 & \\
\hline Total & 44 & 100 & 46 & 100 & \\
\hline
\end{tabular}

According to research by Mendoza et al (2015), showing the effectiveness level of using instructional media such as video presentations as props for learning is very effective. ${ }^{5}$ The research of Obagah and Brisibe (2017), from the analyzed data, shows that the effectiveness of using instructional videos improves student learning experiences because the use of media such as videos improves the teaching and learning process. The fact that visual media helps students retain concepts and ideas. ${ }^{6}$

In addition, there are a number of ways in which videos can make a real difference to the teaching and learning process in higher education. Some evidence suggests that the use of video-based learning can see improvements in teaching methods and learning outcomes. Research by Taslibeyaz et al (2017) shows that in the context of medical education from 2000 to 2014 , especially case studies, it shows that watching videos is beneficial for acquiring clinical skills, changing attitudes, encouraging cognitive learning, and retaining knowledge. ${ }^{7}$ Video learning offers a costeffective and location-free flexible learning method, which is available at any time and can suit the individual needs of the learner, enabling them to study at their own pace and view material repeatedly if necessary. This is seen to have real benefits for students. In addition, the visual benefits of learning via video provide a means of increasing access to demonstrations of action / practice. Students can learn from field experts so they have the opportunity to see expert illustrations up close, and with the option to view them repeatedly if necessary. (Cooper and Higgins, 2015). ${ }^{8}$

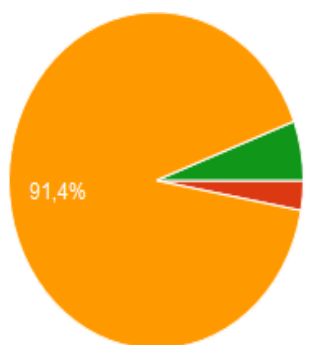

$$
\begin{aligned}
& 1 \text { : Sangat tidak setuju } \\
& 2 \text { : Tidak Setuju } \\
& 3 \text { : Setuju } \\
& 4 \text { : Sangat setuju }
\end{aligned}
$$

Figure 8. Satisfaction Evaluation of the 4C Block Learning Method in the Academic Year 2019-2020

Based on the evaluation of the satisfaction of the $4 \mathrm{C}$ Block Learning Method for the 2019-2020 academic year, it was found that $91.4 \%$ of students agreed with the integrated blended learning system in the I-Learn faculty application as well as a combination of video and peer education.

According to the research by Stockwell et al (2015), video can provide a significant means of improving student learning and increasing student engagement. ${ }^{9}$ Meanwhile, according to the research of Rasi and 
Poikela (2016), videos are used in various ways to support various pedagogical strategies successfully. Not an exhaustive list, in the context of problem-based learning only, video clips can be used to present problems to students to trigger problem solving; to provide information on topics; or to present a solution to a problem at the end of the process ${ }^{10}$.

According to the research by Cynthia (2016), The prevalence of video use in higher education has increased exponentially over the past decade, and this trend is likely to continue in the future. The advancement of the student generation through higher education led to the emergence of new teaching methods (and the role of video in changing some of them), a changing university environment, the development of digital media, and greater knowledge about the benefits of video in college will certainly contribute to sustainable development. this. Furthermore, studies have shown that they can make a positive contribution to students' levels of self- confidence, motivation and performance. In each of these ways, the video is already showing the demonstrable impact of higher levels of education. $^{11}$

But to maximize the benefits of educational videos it is important to remember three main components of cognitive load, elements that influence engagement, and elements that promote active learning. Fortunately, consideration of these elements converges with several recommendations (Cynthia, 2016):

- Keep videos short and targeted at the learning goal.

- Use audio and visual elements to convey appropriate parts of the explanation; consider how to make these elements complementary rather than superfluous.

- Use gestures to highlight important ideas or concepts.

- Use an enthusiastic conversational style to increase engagement

- Embed videos in the context of active learning using guide questions, interactive elements, or related homework assignments.

Additionally, the rapid growth of video instruction in various contexts is accompanied by a wide variety of design options available. This choice must consider the most appropriate content, style and platform to present the material, taking into account the best way to motivate students, improve learning outcomes and even consider students' affective (emotional) states to facilitate optimal learning (Chen and $\mathrm{Wu}, 2015) .^{12}$

\section{CONCLUSION}

a) student learning outcomes have increased and above the average $(47.82 \%)$

b) no student repeats the $4 \mathrm{C}$ block

c) $91.4 \%$ of students responded strongly to the blended learning method and peer education in the $4 \mathrm{C}$ block activities.

\section{ACKNOWLEDGMENT}

This work was supported by LP3M University of Andalas, Medical Faculty anda all of us at Bachelor of Midwifery Medical Faculty of University of Andalas

\section{REFERENCES}

[1] Panduan Blok 4.C Prodi S1 Kebidanan tahun ajaran 2019/2020Sugiyono. Metode Penelitian Kuantitatif, Kualitiatif dan R\&D. Bandung: Alfabeta,CV. 2017.

[2] Jupri,Wahab. 2017. Belajar dan Pembelajaran: Modal Dasar Menjadi Dosen Profesional.

Bandung: Pustaka Reka Cipta

[3] Amir,M.Taufik. 2012. Inovasi Pendidikan Melalui Problem Based Learning. Jakarta: Prenada Media Grup

[4] Mendoza, G, L, L, et al. 2015. Effectiveness of Video Presentation to Students' Learning. International Journal of Nursing Science. 5(2): 81 86. DOI: $10.5923 /$ j.nursing.20150502.07

[5] Obagah, R, R and Brisibe, W, G. 2017. The Effectiveness of Instructional Videos in Enhancing Learning Experience of Architecture Students inDesign and Drawing Courses: A Case Study of Rivers State University, Port-Harcourt. International Journal of Education and Research. Vol. 5 No.11.33 - 46. ISSN: 2411-5681.

[6] Taslibeyaz, E., Aydemir, M. and Karaman, S. (2017), 'An analysis of research trends in articles on video usage in medical education', Education and Information Technologies. 22(3), 873-881

[7] Cooper, D. and Higgins, S. (2015), 'The effectiveness of online instructional videos in the acquisition and demonstration of cognitive, affective and psychomotor rehabilitation skills', British Journal of Educational Technology 46(4), 768-779

[8] Stockwell BR, Stockwell MS, Cennamo M, Jiang E. 2015. Blended learning improves science education. Cell 162, 933-936. 
[9] Rasi, P. and Poikela, S. 2016. A review of video triggers and video production in higher education and continuing education pbl settings. Interdisciplinary Journal of Problem-Based Learning 10(1).

[10] Cynthia J. B., 2016. Effective Educational Videos: Principles and Guidelines for Maximizing Student Learning from Video Content. Center for Teaching and Department of Biological Sciences, Vanderbilt University, Nashville, TN 37203. DOI:10.1187/cbe.16-03-0125

[11] Chen, C.-M. and Wu, C.-H. 2015. Effects of different video lecture types on sustained attention, emotion, cognitive load, and learning performance. Computers \& Education 80, 108- 121. 